\title{
Seasonal Effect and Removal of Disinfection Byproducts from Sakarya River by Ozone and Membrane Processes
}

\author{
Fatma Büşra Yaman ${ }^{1 *}$, Mehmet Çakmakc1 ${ }^{1}$
}

\begin{abstract}
Along the Sakarya River, samples were taken from 2 different points; the first one was the Cifteler where the source of Sakarya River is located and the second one was Karasu area where Sakarya River ran to the Black Sea. Samples were collected during 2 different seasons; in winter and in summer in order to observe the seasonal effect. Trihalomethanes (THMs) and water quality parameters like Dissolved Organic Carbon (DOC), Ultraviolet Absorbance at $254 \mathrm{~nm}$ Wavelength (UV254), hardness, and conductivity values were examined. In order to remove the organic matter and THMs ozone and membrane process were performed. Good treatment efficiency was obtained with ozone and membrane process. The removal efficiencies of THMFP were found to be approximately $70 \%$. Also, all parameters presented higher values in summer compared to winter. It was observed from the FT-IR analysis results that the aromatic and aliphatic functional groups in water changed after the treatment with ozone; and that peak values decreased more after the ozone+membrane treatment. TheSEM analysis showed that some compounds, such as $\mathrm{Ca}, \mathrm{Mg}$, and $\mathrm{Fe}$, have been formed on the surface of the membrane after the purification through the membrane only, however these compounds decreased both in weight and size when membrane filtration is performed after a pre-ozonization.
\end{abstract}

Keywords - THM, membrane, ozone, water quality.

\section{INTRODUCTION}

Surface and ground waters are used to supply drinking water. Chlorine, a disinfectant for water treatment, which is extremely powerful, practical, and also cost-effective has been most widely used since the early twentieth.[1,2] .However, Natural Organic Matter (NOM) present in drinking water sources is a major problematic issue for disinfection, because it produces Disinfection by Products (DBPs) during chlorination [3, 4]. A huge part of DBPs can potentially cause long-term adverse health effects. DBPs are potential carcinogenetic to humans $[5,6]$ Because of the potential health risks of DBPs, many countries and some water agencies, i.e., USEPA and WHO have regulated these compounds in their drinking water quality standard[7, 8]. Due to the tightening of water quality regulations, alternative treatment technologies have been proposed to improve the treatment of organic matters $[9,10]$. Nowadays, advanced treatment methods like membrane, ozone, nanoparticles have been applied $[11,12]$ to

\footnotetext{
${ }^{1}$ Yildiz Technical University, Department of Environmental Engineering, Istanbul, Turkey
}

treat these polutants. Membrane technologies are shown as one of the most influential methods to purify NOM and DBP in many studies conducted in recent years[6, 11]. Another effective treatment process for micropollutants is ozonation. Ozone (O3) can be used in water treatment facilities to remove many organic micropollutants with taste, odor, and color implications [13, 14].

In this study, the samples were collected during two seasons (summer and winter) from two different locations along Sakarya River. The removal of THMFP and DBPs precursors from the water of Sakarya River by membrane and ozone+membrane was investigated. $1 \mathrm{mg} / \mathrm{L}$ ozone dose and UF membrane were used.

\section{MATERIALS AND METHODS}

\section{A. Collecting Samples from the River}

The samples were taken from 2 different points from Sakarya River. The first point was the Cifteler where the source of Sakarya River is located. The second point was the Karasu area where Sakarya River ran to the Black Sea. At the same time samples were collected in summer and in winter in order to observe the effect of seasonal variation. The sampling points are shown in Fig. 1. The samples were kept at $+4^{\circ} \mathrm{C}$.

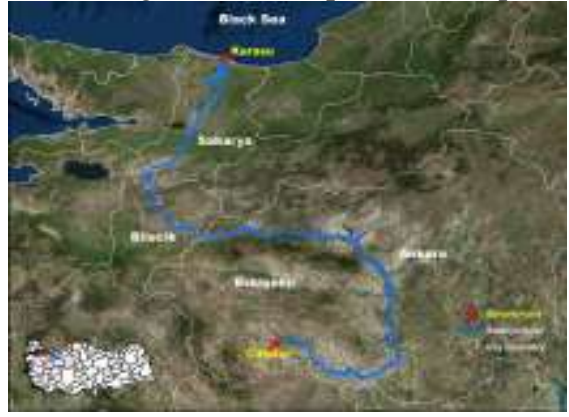

Fig. 1 Sample points

\section{B. Analytical Methods}

DOC measurements were performed using a catalytic combustion based on DOC analyzer. DOC was measured by means of a DOC analyzer (Hach Lange, IL 550). The ultraviolet absorbance $\left(\mathrm{UV}_{254}\right)$ was determined by using a UVVIS scanning spectrophotometer (Genesys 10, Bonsay Technologies, Bhubaneswar, India) with $1-\mathrm{cm}$ cells at the 254 $\mathrm{nm}$ wavelength. Specific Ultraviolet Absorbance (SUVA) was calculated as the ratio of $\mathrm{UV}_{254}$ to DOC. 
Reagents, solutions, calibration standards, internal standards, and surrogate standards for THMs was purchased from Supelco. After filtration with $0.22 \mu \mathrm{m}$ membrane filter, chlorination of samples was carried out at $\mathrm{pH} 7.0$ by the addition of a phosphate buffer solution. An appropriate amount of $5 \mathrm{mg} / \mathrm{ml}$ stock sodium hypochlorite dosing solution was added to the raw water. The THM precursors were measured by the THMFP test and analyzed according to the SM 5710B. THMs including chloroform (TCM), bromodichloromethane (BDCM), dibromochloromethane (DBCM), and bromoform (TBM), were extracted with methyl tertbutylnether (MTBE), and then analyzed by gas chromatography (Shimadzu 2010) with a micro-electron capture detector (USEPA 551.1).

\section{Experimental Set -up}

The experimental scheme of the ozonation is given in Fig. 2(a) and consisted of an ozonator generator (Sander Laboratory Ozonizer 300.5), a reaction column that has $20 \mathrm{~cm}$ diameter and $102 \mathrm{~cm}$ height. Moreover, 2\% Potassium Iodide (KI) bottles were used to capture the excess ozone. The membrane treatment experiment were conducted with crossflow membrane design able to run under pressure with a mixture of $400 \mathrm{~mL}$ sample container and $76 \mathrm{~mm}$ internal diameter as given in Fig. 2 (b). UF10 membrane used had a molecular weight of 10,000 $\mathrm{Da}$ and the working pressure was fixed at 3 bar.

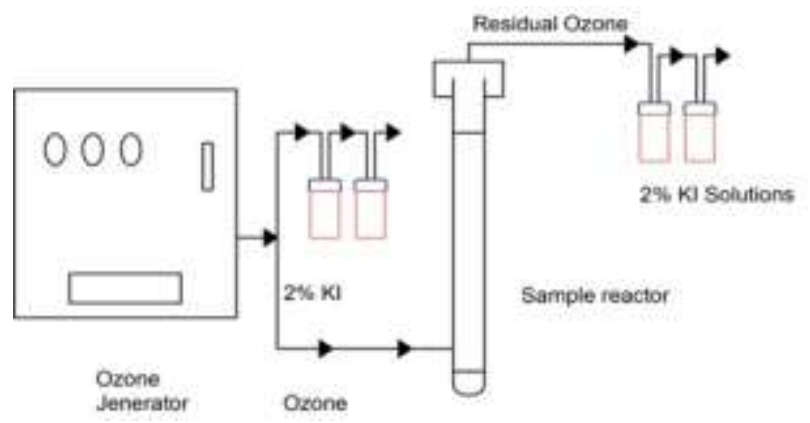

(a)

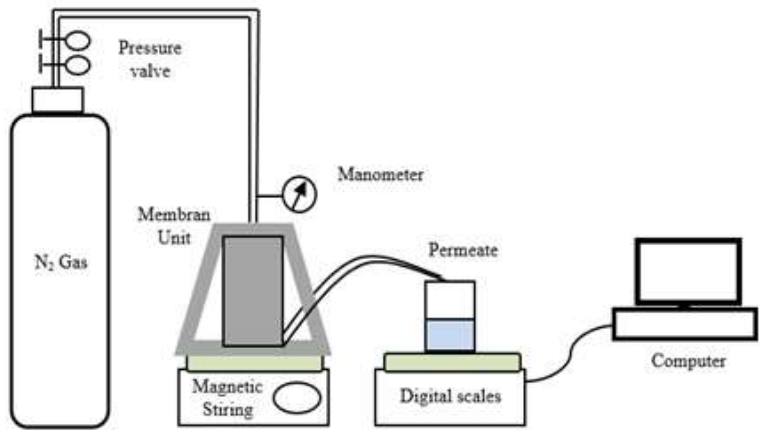

(b)

Fig. 2 Experimental Set up

\section{RESULTS AND DISCUSSION}

\section{A. Characteristics of Water}

The characterization of water samples taken during two different seasons and from two points of the river are given in
Table 1 . The average $\mathrm{pH}$, temperature and conductivity values of the samples were $7.88,9.6^{\circ} \mathrm{C}, 839 \mu \mathrm{S} / \mathrm{cm}$, respectively. DOC values were higher in summer than in winter, the maximum concentration was found to be $13,26 \mathrm{mg} / \mathrm{L}$ in summer from the sample of Karasu. $\mathrm{SUVA}_{254}$ was found to be in the range of $0.15-.1 .13 \mathrm{~L} / \mathrm{mg}$.m, which suggests that the organic substances forming DOC are usually those with low molecular weight $\left(\mathrm{SUVA}_{254}<2\right)[15]$.

\begin{tabular}{|c|c|c|c|c|c|}
\hline \multirow[b]{2}{*}{ Parameter } & \multirow[b]{2}{*}{ Units } & \multicolumn{2}{|c|}{ Summer } & \multicolumn{2}{|c|}{ Winter } \\
\hline & & $\begin{array}{l}\text { Ciftele } \\
\mathbf{r}\end{array}$ & $\begin{array}{l}\text { Karas } \\
\mathbf{u}\end{array}$ & $\begin{array}{l}\text { Ciftele } \\
\mathbf{r}\end{array}$ & $\begin{array}{l}\text { Karas } \\
\mathbf{u}\end{array}$ \\
\hline $\mathrm{nH}$ & - & 7.84 & 8.12 & 7.73 & 7.83 \\
\hline Temprature & ${ }^{0} \mathrm{C}$ & 12.00 & 11.30 & 7.80 & 7.35 \\
\hline Conductivit & $\mu \mathrm{S} / \mathrm{cm}$ & 828.00 & 931.00 & 748.00 & 849.00 \\
\hline $\mathrm{UV}_{254}$ & $\mathrm{~cm}-1$ & 0.03 & 0.16 & 0.01 & 0.11 \\
\hline DOC & $\mathrm{mg} / \mathrm{L}$ & 9.62 & 13.26 & 6.40 & 9.65 \\
\hline SUVA $_{254}$ & L/mg.m & 0.31 & 1.20 & 0.15 & 1.13 \\
\hline
\end{tabular}

\section{B. THMFP Concentration}

In Fig 3 it is observed that both Cifteler and Karasu THM concentration is higher in summer. Maximum and minimum THMFP concentration was found to be $246,78 \mu \mathrm{g} / \mathrm{L}$ in Karasu and $148,46 \mu \mathrm{g} / \mathrm{L}$ in Cifteler. When the THM species distribution is considered, the following order is observed in the samples; TCM $>$ BDCM $>$ DBMC $>$ TBM. According to the results the highest class being $79 \%$ is TCM, whereas the lowest class $1 \%$ is TBM. Reguero et al. (2013), found similar results.

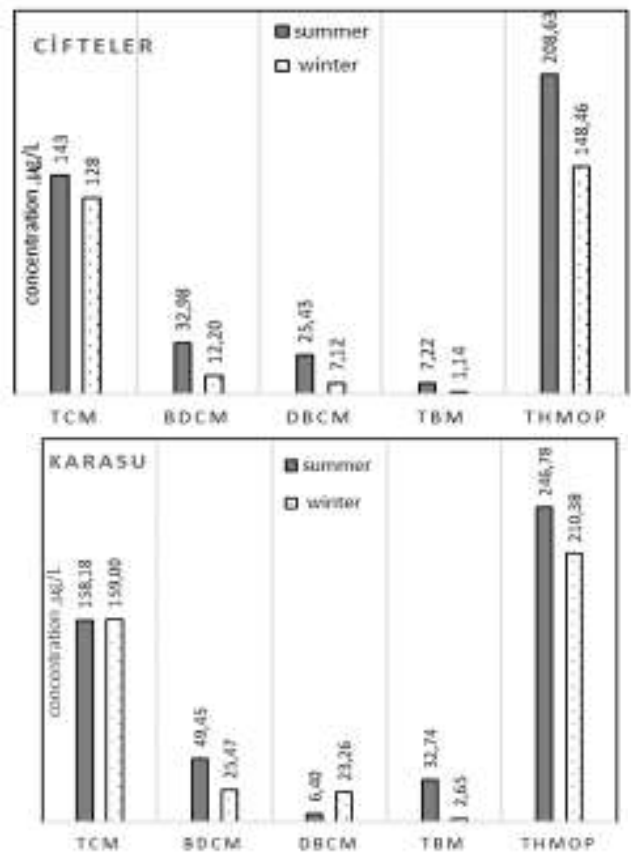

Fig. 3 THM concentration

\section{Membrane Treatment}

DOC, UV and THMFP removal efficiencies with membrane treatments were examined and shown in Fig 4. The UV254 and DOC removal efficiencies of the samples were compared for organic matter removal. The highest UV254 removal was 
obtained in summer, $17 \%$ in Cifteler while the lowest UV254 removal, $12 \%$ was obtained in winter in Karasu. The lowest DOC removal efficiencies, $30 \%$ were obtained in Karasu in winter; and the highest removal efficiency, $36 \%$ was obtained in Cifteler,in summer. It was observed from the examination of the THMFP removal efficiency that the highest rate was determined in Cifteler with $63 \%$, and the lowest rate was determined in Karasu with $55 \%$ in winter.
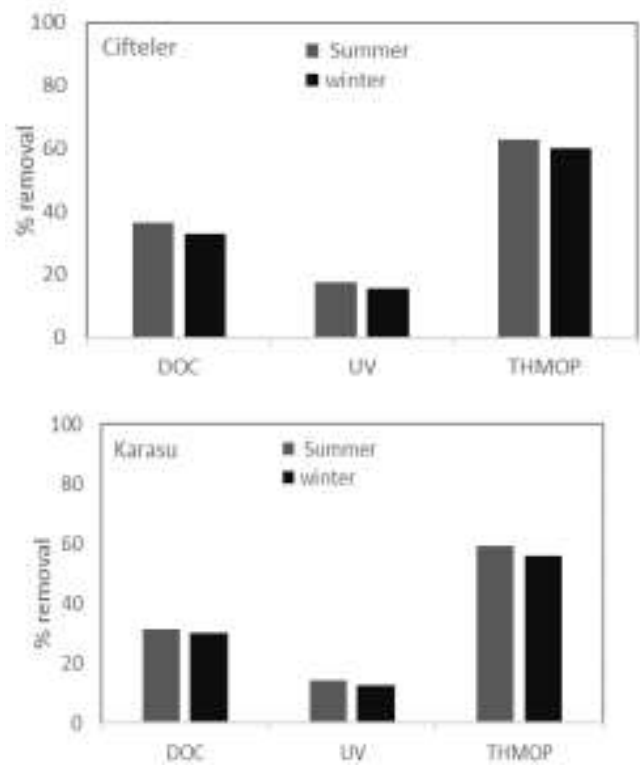

Fig. 4 Organic matter removal efficiency with membrane treatment

\section{Ozone+membrane treatment}

During ozone and membrane treatment, $1 \mathrm{mg} / \mathrm{L}$, ozone dosage was selected. The samples were first treated with ozone, and then filtrated with the membrane. As a result of the treatment with ozone and membrane, maximum DOC, UV, and THMFP removal efficiencies were found to be $44 \%, 21 \%$ and $76 \%$ respectively. It is observed that the removal efficiencies were higher compared to the treatment with membrane only (Fig 5). In THMFP, the highest and the lowest removal efficiencies obtained were $76 \%$ in Cifteler (in summer) and 68\% in Karasu (in winter), respectively.

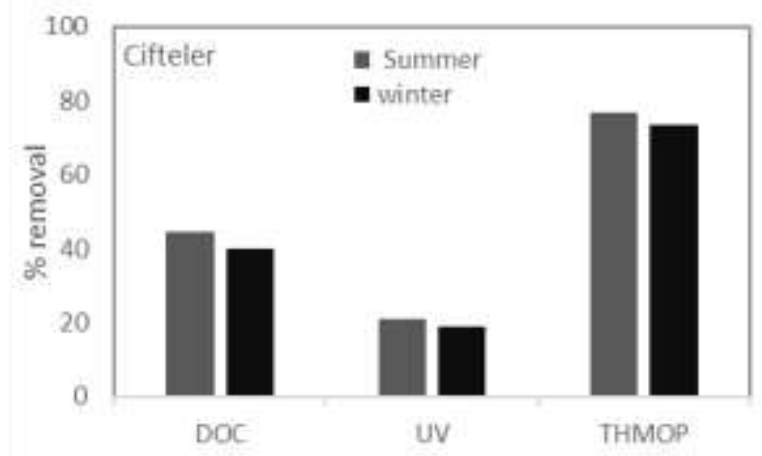

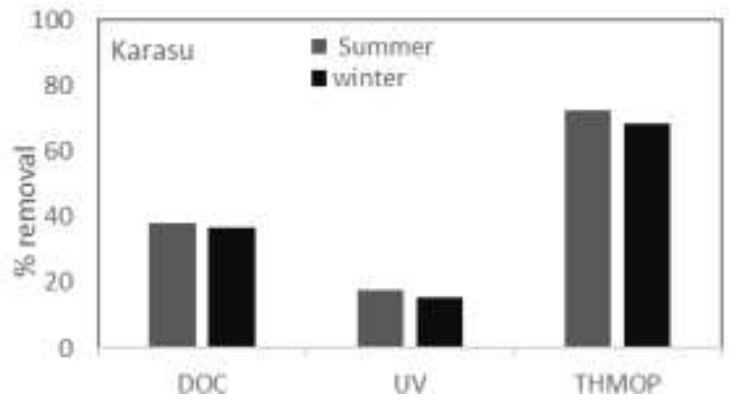

\section{E. ATR-FTIR SPECTRA}

The IR spectroscopy is used for characterization of the organic matter, which can supply valuable information on the structural and functional properties of organic molecules (Wei et al., 2010).For FTIR analysis, the Cifteler sample was chosen. The FTIR analysis results of Cifteler are given in Fig. 5. It is observed that the first peak both in raw water and in the water treated with membrane and ozone is between 3400-3300 $\mathrm{cm}-1$ range. The $3400-3300 \mathrm{~cm}-1$ peak shows the $\mathrm{O}-\mathrm{H}$ stretching bonds[16, 17]. This peak stems from the humic matters like alcohols, phenols and carboxylic acids that are frequently observed in water[18]. The second peak, on the other hand, shows that there are $\mathrm{C}=\mathrm{O}$ aromatic bonds seen in the 1640-1550 cm-1 bandwidth[16, 17]. It was observed that the aromatic structure observed in this band stem from structures like cyclic and alicyclic compounds that have low wave numbers, ketones and aromatic carboxylic acids[18, 19]. According to these results, it is observed that there are some changes, although little, in the peak values with membrane, ozone and ozone+membrane treatments. The decrease in the $\mathrm{O}-\mathrm{H}$ peak value with membrane and ozone+membrane treatments show that some of the humic matters were removed. A higher decrease was observed in the O-H peak values with ozone+membrane than the treatment that was performed with only membrane. In the $\mathrm{C}=\mathrm{O}$ band, there was a decrease with the membrane and membrane+ozone treatment. As it is observed from this decrease, some organic matters like cyclic and alicyclic compounds, ketones and aromatic carboxylic acids are removed. The highest decrease in both peaks occurred in ozone+membrane system.

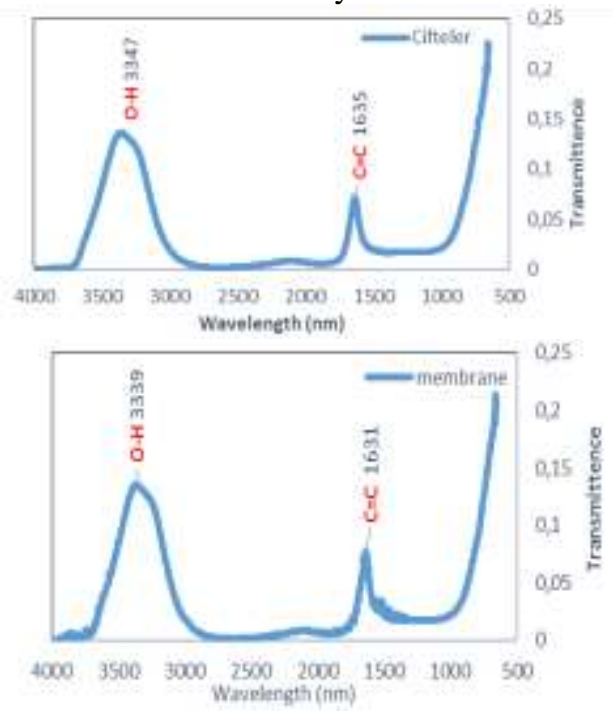




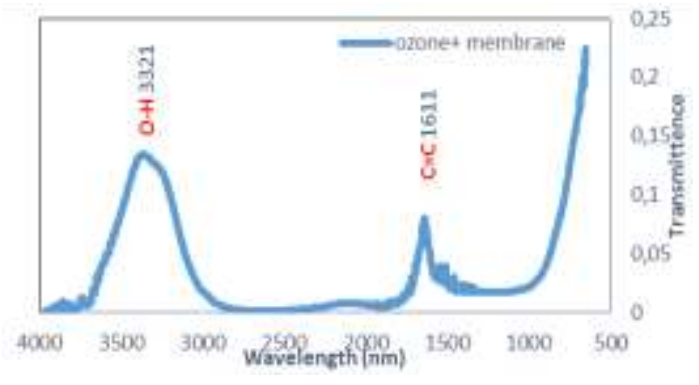

F. SEM analysis

The particle accumulation and blockage on the membrane surface can be understood through SEM analysis. In Fig. 6 are SEM images pertaining to U60 membrane given. While it is seen in 6(a) that there is no particle or accumulation on the surface of the clean membrane, the particles that deposited on the membrane surface after the filtration of the sample of Cifteler can clearly be seen in Fig. 6 (b). In Fig. 6 (c), on the other hand, it is seen that the particles had been broken down after ozonation and turned into smaller structures and that less accumulation occurred on the membrane surface.

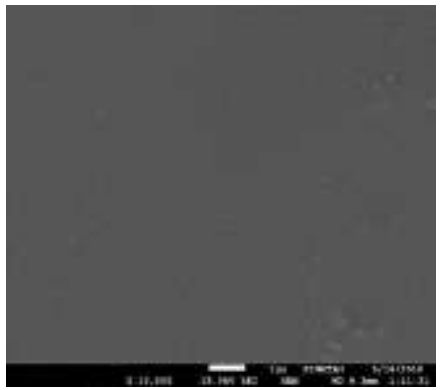

a) clean membrane

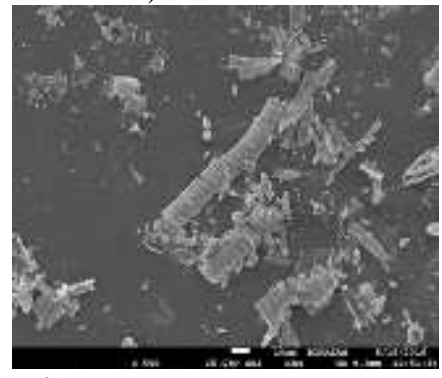

b) membrane sample filtered

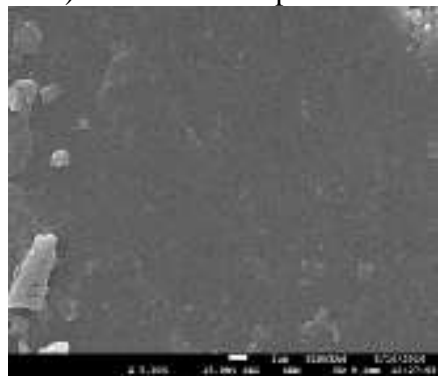

c) membrane +ozone

\section{CONCLUSIONS}

In this study, water samples were taken from 2 different points along Sakarya River starting from the point where it was born and ending at the point where it ran to the sea. The samples were treated with membrane, and ozone+membrane.
The DOC, $\mathrm{UV}_{254}, \mathrm{SUVA}_{254}$, THMFP removal efficiencies were examined.

According to the results of the study;

- Experimental results and investigation showed that the highest total THMs levels were detected in summer while the lower levels in winter.

- According to the results, the first point (Cifteler) where the source of Sakarya River is located has better water quality parameters than the end of the river. It means; along the river, water was polluted due to external factors.

- The comparison of the treatment methods used during the study showed that the highest removal efficiency of $76 \%$ THMFP, $21 \%$ UV and $44 \%$ DOC was possible with the combination of ozone+ membrane system.

- The FTIR analysis results showedthat there was an increase on the membrane surface in most of the functional groups after the treatment/purification through the membrane.

It was observed from SEM and EDX results that a cakelike layer occurred on the membrane surface when Cifteler sample was filtered.

\section{REFERENCES}

[1] M. Serrano, I. Montesinos, M.J. Cardador, M. Silva, M. Gallego, Seasonal evaluation of the presence of 46 disinfection by-products throughout a drinking water treatment plant, The Science of the total environment, 517 (2015) 246-258. http://dx.doi.org/10.1016/j.scitotenv.2015.02.070

[2] A. Domínguez-Tello, A. Arias-Borrego, T. García-Barrera, J.L. GómezAriza, Seasonal and spatial evolution of trihalomethanes in a drinking water distribution system according to the treatment process, Environmental Monitoring and Assessment, 187 (2015). http://dx.doi.org/10.1007/s10661-015-4885-8

[3] R. Lamsal, K.R. Montreuil, F.C. Kent, M.E. Walsh, G.A. Gagnon, Characterization and removal of natural organic matter by an integrated membrane system, Desalination, 303 (2012) 12-16. http://dx.doi.org/10.1016/j.desal.2012.06.025

[4] L. Monteiro, R.M.C. Viegas, D.I.C. Covas, J. Menaia, Modelling chlorine residual decay as influenced by temperature, Water and Environment Journal, 29 (2015) 331-337. http://dx.doi.org/10.1111/wej.12122

[5] A. Tubic, J. Agbaba, B. Dalmacija, J. Molnar, S. Maletic, M. Watson, S.U. Perovic, Insight into changes during coagulation in NOM reactivity for trihalomethanes and haloacetic acids formation, Journal of environmental management, 118 (2013) 153-160. http://dx.doi.org/10.1016/j.jenvman.2012.11.046

[6] W. Huang, H. He, B. Dong, H. Chu, G. Xu, Z. Yan, Effects of macroporous anion exchange and coagulation treatment on organic removal and membrane fouling reduction in water treatment, Desalination, 355 (2015) 204-216. http://dx.doi.org/10.1016/j.desal.2014.10.045

[7] M. Kumari, S.K. Gupta, Modeling of trihalomethanes (THMs) in drinking water supplies: a case study of eastern part of India, Environmental science and pollution research international, 22 (2015) $12615-12623$ http://dx.doi.org/10.1007/s11356-015-4553-0

[8] M. Sadrnourmohamadi, B. Gorczyca, Effects of ozone as a stand-alone and coagulation-aid treatment on the reduction of trihalomethanes precursors from high DOC and hardness water, Water research, 73 (2015) 171-180. http://dx.doi.org/10.1016/j.watres.2015.01.023

[9] N. Ates, L. Yilmaz, M. Kitis, U. Yetis, Removal of disinfection byproduct precursors by UF and NF membranes in low-SUVA waters, Journal of Membrane Science, 328 (2009) 104-112.

http://dx.doi.org/10.1016/j.memsci.2008.11.044 
[10] V. Reguero, R. López-Fernández, J. Fermoso, O. Prieto, P. Pocostales, R. González, R. Irusta, S. Villaverde, Comparison of conventional technologies and a Submerged Membrane Photocatalytic Reactor (SMPR) for removing trihalomethanes (THM) precursors in drinking water treatment plants, Desalination, 330 (2013) 28-34. http://dx.doi.org/10.1016/j.desal.2013.09.014

[11] C. Stoquart, P. Servais, P.R. Bérubé, B. Barbeau, Hybrid Membrane Processes using activated carbon treatment for drinking water: A review, Journal of Membrane Science, 411-412 (2012) 1-12. http://dx.doi.org/10.1016/j.memsci.2012.04.012

[12] K. Doederer, M.J. Farré, M. Pidou, H.S. Weinberg, W. Gernjak, Rejection of disinfection by-products by RO and NF membranes: Influence of solute properties and operational parameters, Journal of Membrane Science, 467 (2014) 195-205. http://dx.doi.org/10.1016/j.memsci.2014.05.029

[13] Y.-h. Wang, K.-c. Chen, C.-r. Chen, Combined catalytic ozonation and membrane system for trihalomethane control, Catalysis Today, 216 (2013) 261-267. http://dx.doi.org/10.1016/j.cattod.2013.06.018

[14] C. Chen, X.J. Zhang, L.X. Zhu, J. Liu, W.J. He, H.D. Han, Disinfection by-products and their precursors in a water treatment plant in North China: Seasonal changes and fraction analysis, The Science of the total environment, 397 (2008) 140-147.

http://dx.doi.org/10.1016/j.scitotenv.2008.02.032

[15] J. Lowe, M.M. Hossain, Application of ultrafiltration membranes for removal of humic acid from drinking water, Desalination, 218 (2008) 343-354. http://dx.doi.org/10.1016/j.desal.2007.02.030

[16] L. Wei, K. Wang, Q. Zhao, J. Jiang, C. Xie, W. Qiu, Organic matter extracted from activated sludge with ammonium hydroxide and its characterization, Journal of Environmental Sciences, 22 (2010) 641647. http://dx.doi.org/10.1016/S1001-0742(09)60157-1

[17] K. Jeong, D.-S. Lee, D.-G. Kim, S.-O. Ko, Effects of ozonation and coagulation on effluent organic matter characteristics and ultrafiltration membrane fouling, Journal of Environmental Sciences, 26 (2014) 13251331. http://dx.doi.org/10.1016/S1001-0742(13)60607-5

[18] B. Pernet-Coudrier, G. Varrault, M. Saad, J.P. Croue, M.F. Dignac, J.M Mouchel, Characterisation of dissolved organic matter in Parisian urban aquatic systems: predominance of hydrophilic and proteinaceous structures, Biogeochemistry, 106 (2010) 89-106. http://dx.doi.org/10.1007/s10533-010-9480-z

[19] F.J. Rodriguez, P. Schlenger, M. Garcia-Valverde, Monitoring changes in the structure and properties of humic substances following ozonation using UV-Vis, FTIR and (1)H NMR techniques, The Science of the total environment, 541 (2016) 623-637.

http://dx.doi.org/10.1016/j.scitotenv.2015.09.127 